\title{
Actions of sesquiterpene lactones isolated from Moquiniastrum polymorphum subsp. floccosum in MCF7 cell line and their potentiating action on doxorubicin
}

Mariana de Oliveira Mauro ${ }^{1}$, Renata Matuo ${ }^{2}$, Natan de David², Regiane Lauriano Batista Strapasson³, Rodrigo Juliano Oliveira $24^{*}$, Maria Élida Alves Stefanello ${ }^{3}$, Cândida Aparecida Leite Kassuya ${ }^{5}$, Maria de Fátima de Cepa Matos ${ }^{2}$, Fábio José Carvalho Faria ${ }^{6}$ and Deiler Sampaio Costa ${ }^{1,6}$

\begin{abstract}
Background: In order to obtain better clinical results in anticancer therapies, polychemotherapy or combination therapies are used. For this, the combinations are required to increase the efficacy and reduce the adverse reactions of the associated chemotherapies. The aim of this study was to evaluate the cytotoxic, apoptotic and (anti)proliferative potential of two sesquiterpene lactones isolated from Moquiniastrum polymorphum, 11,13-diidrozaluzanin C (1) and gochnatiolide C (2), and their associations with chemotherapeutic agents irinotecan, tamoxifen, cisplatin, 5-fluouracyl and doxorubicin in the tumoral lineage of MCF-7 breast adenocarcinoma.

Methods: The analyses were performed by MTT cytotoxicity assays, drug combination index (CI), apoptosis morphological assay and cell proliferation assay. Treatments were evaluated with short exposure times $(4 \mathrm{~h})$, followed or not by recovery in drug-free medium for $24 \mathrm{~h}$. For the cell viability assay the statistical analysis was performed using software INSTAT, and the ANOVA/Tukey test was applied. Combination Indices (CI) was made using CompuSyn software and demonstrated through isoboles. The assays that evaluated cell death and proliferation used statistical analysis SAS 9.4 (Statistical Analysis System), and the procedure adopted was PROC NPAR1WAY. The Wilcoxon test at 5\% level was applied for comparing statistical differences.

Results: The results demonstrated that the compounds decrease cell viability and increase their action when associated with irinotecan, tamoxifen and doxorubicin $(\mathrm{Cl}<1$ and $\mathrm{Cl}=1)$. In periods of $4 \mathrm{~h}$-exposure, the compounds cause cell death by apoptosis and after $24 \mathrm{~h}$, they increase the mean number of cells in programmed cell death, especially when treated with 2. In addition, the association with doxorubicin increases the apoptotic potential induced by tested compounds. Both isolates had effect on the reduction of the number of mitoses, especially when 2 at its highest concentration is associated with doxorubicin.

(Continued on next page)
\end{abstract}

\footnotetext{
*Correspondence: rodrigo.oliveira@ufms.br

2Programa de Mestrado em Farmácia, Centro de Ciências Biológicas e da

Saúde (CCBS), Universidade Federal de Mato Grosso do Sul (UFMS), Campo

Grande, Mato Grosso do Sul, Brazil

${ }^{4}$ Centro de Estudos em Células Tronco, Terapia Celular e Genética

Toxicológica (CeTroGen), Hospital Universitário Maria Aparecida Pedrossian

(HUMAP), Universidade Federal de Mato Grosso do Sul (UFMS), Campo

Grande, Mato Grosso do Sul, Brazil

Full list of author information is available at the end of the article
}

(c) The Author(s). 2017 Open Access This article is distributed under the terms of the Creative Commons Attribution 4.0 International License (http://creativecommons.org/licenses/by/4.0/), which permits unrestricted use, distribution, and reproduction in any medium, provided you give appropriate credit to the original author(s) and the source, provide a link to the Creative Commons license, and indicate if changes were made. The Creative Commons Public Domain Dedication waiver (http://creativecommons.org/publicdomain/zero/1.0/) applies to the data made available in this article, unless otherwise stated. 
(Continued from previous page)

Conclusions: Finally, these compounds are presented as potential agents in chemotherapy combined with doxorubicin, since they trigger the mechanism of apoptosis, which, through the mechanism of action of sesquiterpene lactones, leads to a reduction in toxicity. In addition, the tested compounds have the ability to exert a synergistic action with doxorubicin, possibly by down-regulating the drug resistance mechanisms.

Keywords: Moquiniastrum, Breast cancer, Sesquiterpene lactones, Cytotoxicity, Apoptosis

\section{Background}

Cancer is the largest public health problem in the Americas, and breast cancer is the most common type among women, accounting for about $25 \%$ of new cases each year $[1,2]$.

Therapeutic strategies for this type of neoplasia have posed a challenge because the disease is complex and has several subtypes, which directly influences the choice of therapy, clinical outcomes and prognosis $[1,3]$. This facts lead to the search for effective therapies.

In general, chemotherapeutic agents are toxic, and this effect becomes more enhanced in rapidly proliferating tissues as cell cycles are shorter. This phenomenon causes greater toxicity of the agents in tissues such as mucosae and cells of the immunological system since they are capable of accumulating more damage. Another important aspect is the ability of the neoplastic cell to undergo mutations that can trigger resistance to chemotherapeutics, thus reducing therapeutic efficacy $[4,5]$. This condition is associated with the fact that cell cycles of tumor cells occur within a shorter period of time and more frequently [5].

In order to obtain better clinical results in anticancer therapies, polychemotherapy or combination therapies are used, which consist of the association of more than one cytostatic/cytotoxic agent with distinct mechanisms of action so as to delay tumor resistance [6] and to better induce tumor cell death or tumor eradication [7]. For this, the combinations are required to increase the efficacy and reduce the adverse reactions of the associated chemotherapies, which generates additive and/or synergistic effects [8].

The plants, widely used in traditional medicine for the treatment of diseases, are important sources of bioactive substances and, among them, secondary metabolites such as sesquiterpene lactones are highlighted for having a recognized antitumor effect $[9,10]$.

Approximately 1500 genera and 23,000 species constitute the plants of the family Asteraceae, the species Moquiniastrum polymorphum, native to Brazil, Paraguay, Uruguay and Argentina, is used in folk medicine for the treatment of respiratory diseases, sore throat and gastritis [11] and has anti-inflammatory, antispasmodic and antimicrobial action $[12,13]$, besides antioxidant, cytotoxic and antitumor activity $[11,14]$.
Previous studies of our group have evaluated the antiproliferative capacity of six sesquiterpene lactones isolated from Moquiniastrum polymorphum [10], among them 11,13-dihydrozaluzanin $C$ (1) and 10-desoxigochnatiolide A (2, gochnatiolídeo C), also used in this study. The assay was performed in 10 different human cancer cell lines, showing that 1 was inactive, while 2 presented an activity similar to that of doxorubicin, which was used as a positive control. A lactones mixture also showed antitumor activity against the Walker-256 tumor in rats [14].

To this end, cytotoxic and cytostatic activities were evaluated, and also the ability to induce apoptosis of sesquiterpene lactones 11,13-diidrozaluzanin C (1) and gochnatiolide C (2) isolated from Moquiniastrum polymorphum subsp. floccosum. Their effect in association with different commercial antitumor agents was also assessed.

\section{Methods}

\section{Cell line and culture conditions}

MCF-7 breast adenocarcinoma cell line and cell cultures were kindly provided by Professor Maria de Fátima Cepa Matos, of the Laboratory of Molecular Biology of the Center of Biological Sciences of the Federal University of Mato Grosso do Sul. The cells were cultured in Dulbecco's Modified Eagle Medium (DMEM-Gibco ${ }^{\circ}$ ), supplemented with $10 \%$ fetal bovine serum (v/v), $0.1 \%$ penicillin $(100 \mathrm{U} / \mathrm{ml}) /$ streptomycin $(100 \mu \mathrm{g} / \mathrm{ml})(\mathrm{v} / \mathrm{v})$, in incubator at $37{ }^{\circ} \mathrm{C}$ with $5 \% \mathrm{CO}_{2}$ atmosphere.

\section{Chemical agents}

As damage-inducing agents, the following chemotherapeutics were used at their respective concentrations of $\mathrm{IC}_{50}$ previously determined by pilot studies on MCF-7 cells: $0.3 \mu \mathrm{M}$ doxorubicin $\left(\right.$ Bergamo $\left.^{\circ}\right) ; 5.0 \mu \mathrm{M}$ cisplatin (Gunther $^{\circ}$ ); 5-Fluouracyl 1.25 $\mu \mathrm{M}$ (Biosynthetic ${ }^{\oplus}$ ); $12 \mu \mathrm{M}$ Tamoxifen (Sanofi Aventis ${ }^{\oplus}$ ); and $5 \mu \mathrm{M}$ irinotecan (Janssen Cilag ${ }^{\circledR}$ (Fig. 1).

The sesquiterpene lactones of $M$. polymorphum were obtained as previously described $[10,15]$. Compound 1 (11,13-diidrozaluzanin C) was tested at concentrations of $40 ; 100 ; 200 ; 300$ and $400 \mu \mathrm{M}$, and compound 2 (gochnatiolide $\mathrm{C}$ ) at concentrations of $0.5 ; 1.0 ; 2.0 ; 3.0$ and $4.0 \mu \mathrm{M}$, diluted in dimethyl sulfoxide (DMSO) at $1.0 \%$ in all experiments. DMSO was also added in the 


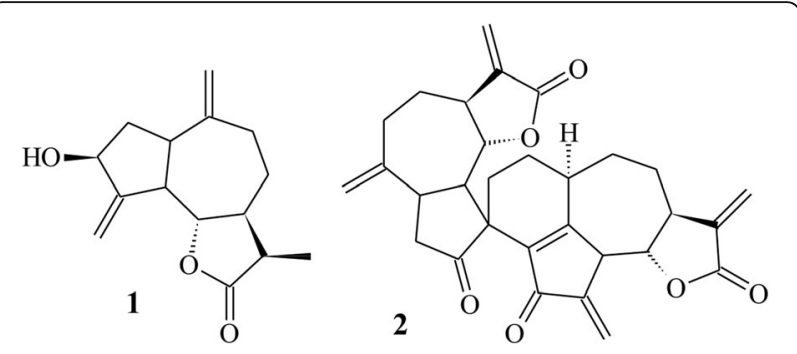

Fig. 1 Chemical structures of 11,13-dihydrozaluzanin C (1) and gochnatiolide C (2)

same percentage to controls. The concentrations tested of compounds 1 and 2 were defined according to previous results [10].

\section{Cell viability assay}

Cell viability was determined by colorimetric test MTT (3-(4,5-dimetilltiazol-2-il)-2,5-difeniltetrazol bromide), based on the protocol of Poindessous et al. [16] and Mauro et al. [17]. $3 \times 10^{3}$ MCF-7 cells were seeded per well in 96-well plates and maintained for $24 \mathrm{~h}$ in ${\mathrm{a} \mathrm{CO}_{2}}$ incubator for stabilization. The treatments were performed for $72 \mathrm{~h}$ at different doses of chemotherapeutic agents, being thus distributed for the determination of $\mathrm{IC}_{50}$ : doxorubicin $\left(\right.$ Bergamo $^{\circ}$ ) $0.1 ; 0.3 ; 0.4 ; 0.5 \mu \mathrm{M}$; cisplatin (Gunther ${ }^{\oplus}$ ) 2.5; 5.0; 10; 25; $50 \mu \mathrm{M}$; 5-Fluouracyl (Biosynthetic $^{\oplus}$ ) $0.1 ; 1.0 ; 2.5 ; 5 ; 10 \mu \mathrm{M}$; tamoxifen (Sanofi Aventis $^{\circ}$ ) 2.5; 5; 7.5; $10 \mu \mathrm{M}$ and irinotecan (Janssen Cilag $^{\circledast}$ ) 10; 20; 40; $60 \mu \mathrm{M}$.

In the same way was carried out for the isolated compounds, using the following concentrations: compound 1 (400; 100; 200; 300 and $400 \mu \mathrm{M})$ and 2 (0.5; 1.0; 2.0; 3.0 and $4.0 \mu \mathrm{M})$ and simultaneously associated with $\mathrm{IC}_{50}$ of different commercial chemotherapeutics (determined by the methodology explained above). At the end of treatments, the plates were incubated with MTT $3.5 \mathrm{mg} \mathrm{mL}^{-1}$ for $4 \mathrm{~h}$. The culture medium was removed and DMSO was added to permit absorbance reading in a spectrophotometer (Robonik ${ }^{\oplus}$ ) in a $540 \mathrm{~nm}$ filter. For each experiment three independent replicates were performed in quintuplicates. Statistical analysis was performed using software INSTAT, and the ANOVA/Tukey test was applied.

From the cell viability curves of 1 and 2 in combination with the different chemotherapeutic agents, the Combination Indices $(\mathrm{CI})$ were calculated from the values of the affected cell fractions (FA), where: $\mathrm{CI}<1$ indicates synergism; $\mathrm{CI}=1$ indicates additive effect and CI $>1$ indicates antagonistic effect. The calculation dos $\mathrm{CI}$ and normalized isobolograms were made according to the method described by Chou and Talalay [18] using CompuSyn software (http://www.combosyn.com/).

\section{Evaluation of cell death}

Cell deaths were evaluated by morphological assay according to the protocol of Oliveira et al. [19], and classified into apoptotic or necrotic ones. The technique of differential staining with acridine orange and ethidium bromide was used for detecting cell viability, apoptosis and necrosis indices. A total of $5 \times 10^{5}$ cells were seeded in 12-well plates and kept in incubator for $24 \mathrm{~h}$. The evaluation occurred in two different times: i) after $4 \mathrm{~h}$ of treatment $(4 \mathrm{~h})$, and ii) $4 \mathrm{~h}$-treatment followed by $24 \mathrm{~h}$ in drug-free medium $(4 \mathrm{~h}+24 \mathrm{~h})$. For each experiment, two independent replicates were performed, using the doses of 14,28 and $56 \mu \mathrm{M}$ for 1 ; and $0.5 ; 1.0$ and $2.0 \mu \mathrm{M}$ for 2 . These same doses were associated with $0.3 \mu \mathrm{M}$ doxorubicin. The cells were collected by trypsinization, centrifuged at $1200 \mathrm{rpm}$ for $5 \mathrm{~min}$ and the supernatant was discarded. The slides were prepared with $20 \mu \mathrm{L}$ of cell suspension and $2 \mu \mathrm{L}$ of dye containing ethidium bromide $\left(100 \mu \mathrm{g} \mathrm{ml}^{-1}\right)$ and acridine orange $(100 \mu \mathrm{g} \mathrm{mL}$

${ }^{-1}$ ) in a ratio 1:1. Two independent repetitions were performed with two replicates, and 100 cells per replicate were analyzed under an epifluorescence microscope (MOTIC ${ }^{\oplus}$, Model BA410) in a 400x magnification.

Cell classification was performed according to the following description: (i) living cells with functional membrane have uniform green coloration in their nucleus; (ii) cells in initial apoptosis with functional membrane, but with DNA fragmentation, show a green coloration in nucleus and cytoplasm, with a visible marginalization of their nuclear content; (iii) cells in final apoptosis present orange-stained areas both in the cytoplasm and in the sites where the chromatin is condensed in the nucleus, which distinguishes them from necrotic cells; (iv) necrotic cells have uniform orange staining in the nucleus.

Statistical analysis was performed using SAS 9.4 (Statistical Analysis System), and the procedure adopted was PROC NPAR1WAY. The Wilcoxon test at 5\% level was applied for comparing statistical differences.

\section{Cell Proliferation Assay}

For assessing cell proliferation, the cells were labeled with 5-bromo deoxyuridine (BrdU), a synthetic nucleoside analogous to thymidine, incorporated into the newly synthesized DNA strands of cells in replication process as a replacement for thymidine. Thus, the greater the incorporation of BrdU, the greater the proliferative activity of the cells analyzed, since this points to an increased DNA synthesis.

In the assay, $7.5 \times 10^{5}$ cells were seeded on coverslips in 6-well plates and maintained in culture for a period of $24 \mathrm{~h}$ for stabilization and fixation of cells on the coverslips. They were then treated with 1 and 2 at concentrations of $28 \mu \mathrm{M}$ and $1 \mu \mathrm{M}$, respectively; and these same concentrations were associated with doxorubicin 
$(0.3 \mu \mathrm{M})$ for $6 \mathrm{~h}$. BrdU was added in the last $1 \mathrm{~h}$ of treatment. After this time, the cells were washed with phosphate buffer, fixed with $4 \%$ paraformaldehyde, and the DNA denatured with $2 \mathrm{M} \mathrm{HCl}$ was deposited on the coverslip at room temperature. The cells were incubated with PBS containing 5\% fetal bovine serum for $2 \mathrm{~h}$, followed by incubation with anti-BrdU antibody for $1 \mathrm{~h}$. The cells were washed with phosphate buffer and incubated with secondary antibody AlexaFluor 568 for $1 \mathrm{~h}$.

For the analysis, 200 cells were counted and separated as BrdU-labeled cells and unlabeled cells. We also calculated the Mitotic Activity Reduction Ratio (MARR) obtained from the average of the control mean divided by the results obtained in the means of tests. Software SAS 9.4 (Statistical Analysis System) was used for statistical analysis; the procedure adopted was PROC NPAR1WAY; and the Wilkoxon test was applied at 5\% level to compare statistical differences. The Kruskal-Wallis test was employed for analyzing the statistical significance of the results in both protocols.

\section{Results}

Determination of the $\mathrm{IC}_{50}$ of the commercial chemotherapeutic agents, for association with the isolated compounds

Figure 2 shows the graphs that indicate the values of affected cells fraction (FA) and viable cells after exposure of cells MCF-7 to different concentrations of commercial chemotherapeutic agents. The point of intersection of these two parameters determines the concentration of $\mathrm{IC}_{50}$, in order to determine this concentration is necessary for the values of FA and of viable cells should be $50 \%$, converging at a common point of the chart. The $\mathrm{IC}_{50}$ of chemotherapeutic agents were trade thus defined: $0.3 \mu \mathrm{M}$ doxorubicin; 5.0 $\mu \mathrm{M}$ cisplatin; 5-Fluouracyl $1.25 \mu \mathrm{M}$; $12 \mu \mathrm{M}$ Tamoxifen; and $5 \mu \mathrm{M}$ irinotecan.

\section{M. polymorphum subsp. floccosum isolates decrease the cell viability of the MCF-7 lineage and increase the activity of the chemotherapeutic agents irinotecan, tamoxifen and doxorubicin}

The results of the test of MTT assay performed with the compounds 1 and 2 can be viewed on the panels formed by the graphics of cellular viability available in Fig. 3 (lactone 1) and Fig. 4 (lactone 2). The MTT assay demonstrated that the sesquiterpene lactone 1 (Fig. 3) reduced the cell viability of MCF-7 to less than $50 \%$ the number of cells at the lowest concentration tested $(40 \mu \mathrm{M})$ after $72 \mathrm{~h}$ of treatment, yielding a cell viability value of $40.30 \%$.

In turn, sesquiterpene lactone 2 (Fig. 4) led to a reduction in MCF-7 cell viability in near $50 \%$ at concentration of $1 \mu \mathrm{M}(49.78 \%)$ after $72 \mathrm{~h}$ of exposure to 2 .

Supported by the cell viability of each one of the concentrations, $\mathrm{IC}_{50}$ was calculated for these two compounds, estimated at $28 \mu \mathrm{M}$ and $1 \mu \mathrm{M}$, respectively.

Compound 1 at $40 \mu \mathrm{M}$ concentration, in combination with irinotecan (Fig. 3a), tamoxifen (Fig. 3b) and doxorubicin (Fig. 3e), increased the induction of cell death by $3.68 \%, 11.03 \%$ and $17.71 \%$, respectively, when compared with the treatment in which only 1 was added. The association with cisplatin (Fig. 3c) did not alter cell viability.

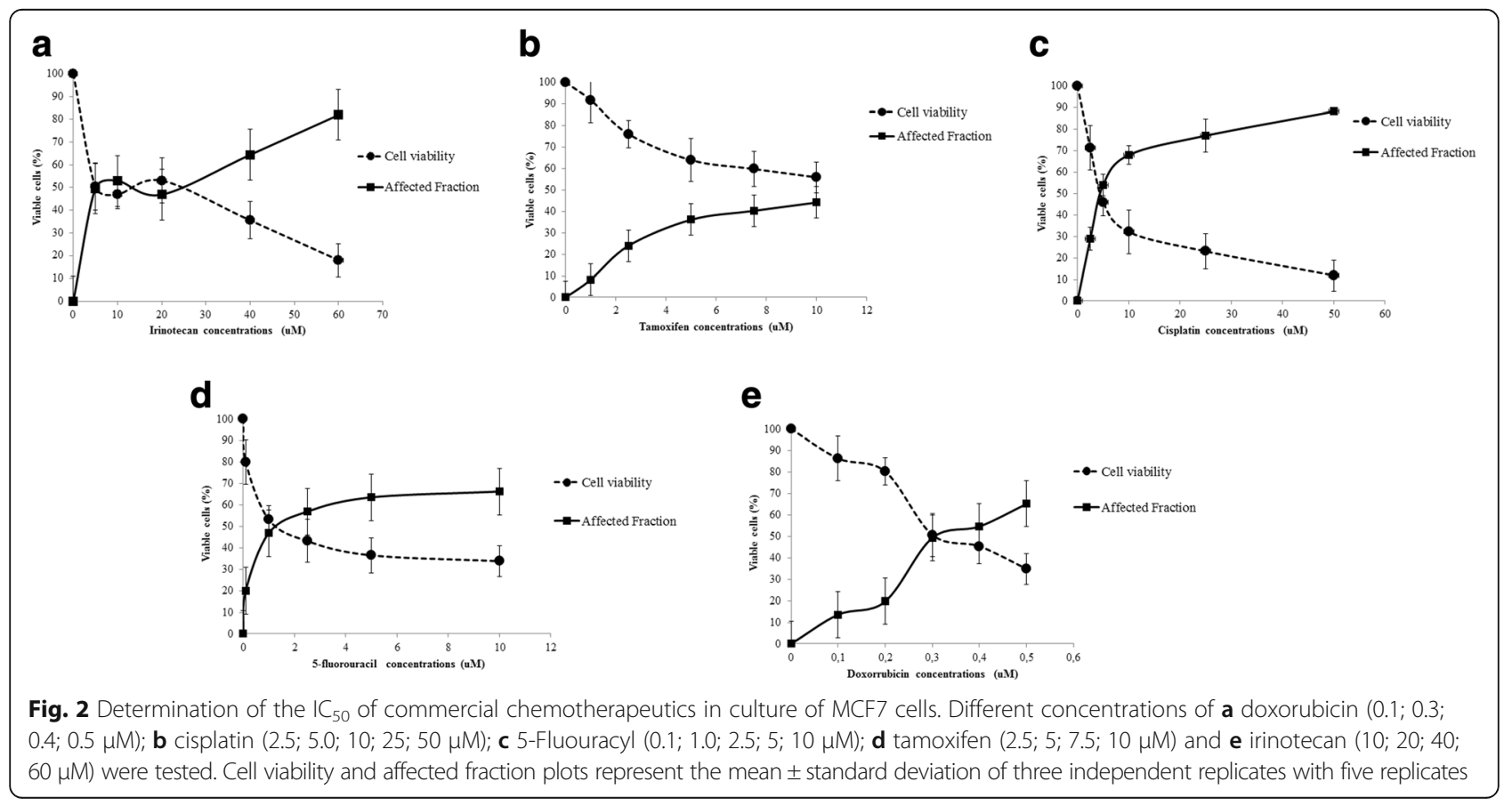




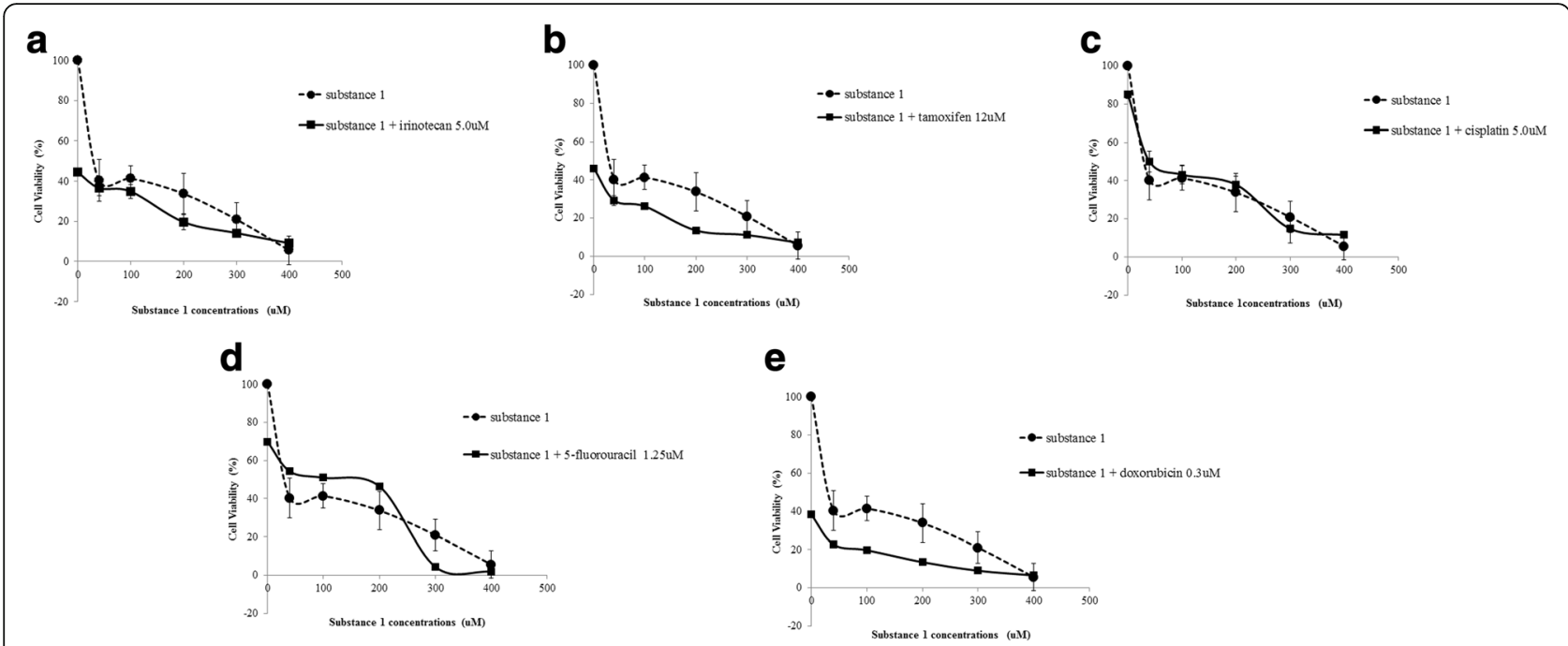

Fig. 3 Effects of 1 on the cell viability of the MCF7 cell line. Different concentrations of 1 (40; 100; 200; 300 and $400 \mu$ M) were combined with the IC 50 of the chemotherapeutic agents a irinotecan, $\mathbf{b}$ tamoxifen, $\mathbf{c}$ cisplatin, $\mathbf{d}$ 5-Fluouracyl and e doxorubicin. Cell viability plots represent the mean \pm standard deviation of three independent replicates with five replicates

The association with 5-fluorouracyl reduced the ability to induce cell death by $9.75 \%$ (Fig. 3d).

In the associated treatments of 2 with the different antineoplastic agents, a reduction of viable cells was observed, especially in the estimated $\mathrm{IC}_{50}(28 \mu \mathrm{M})$ in combinations with irinotecan (Fig. 4a), tamoxifen (Fig. 4b), cisplatin (Fig. 4c), and doxorubicin (Fig. 4e). The increase in nonviable cells, when compared with the compound alone, was $29.41 \%, 28.37 \%, 29.6 \%$ and $27.61 \%$, respectively. Only the combination with 5-fluorouracyl (Fig. 4d) did not present a decrease in viable cells.
Combinations of 1 with irinotecan and tamoxifen showed additive effect and synergism (Fig. $5 \mathrm{a}$ and b) while the association with doxorubicin (Fig. 5e) showed synergism at all concentrations. On the other hand, the combinations of 1 with cisplatin (Fig. 5c) and 5-fluorouracyl (Fig. 5d) presented antagonism and additive effect.

Combinations of 2 with irinotecan showed synergism (Fig. 6a), whereas associations with tamoxifen (Fig. 6b) and doxorubicin (Fig. 6e) indicated synergism and additive effect. The combinations of 2 with cisplatin (Fig. 6c) showed additive effect and antagonism, whereas

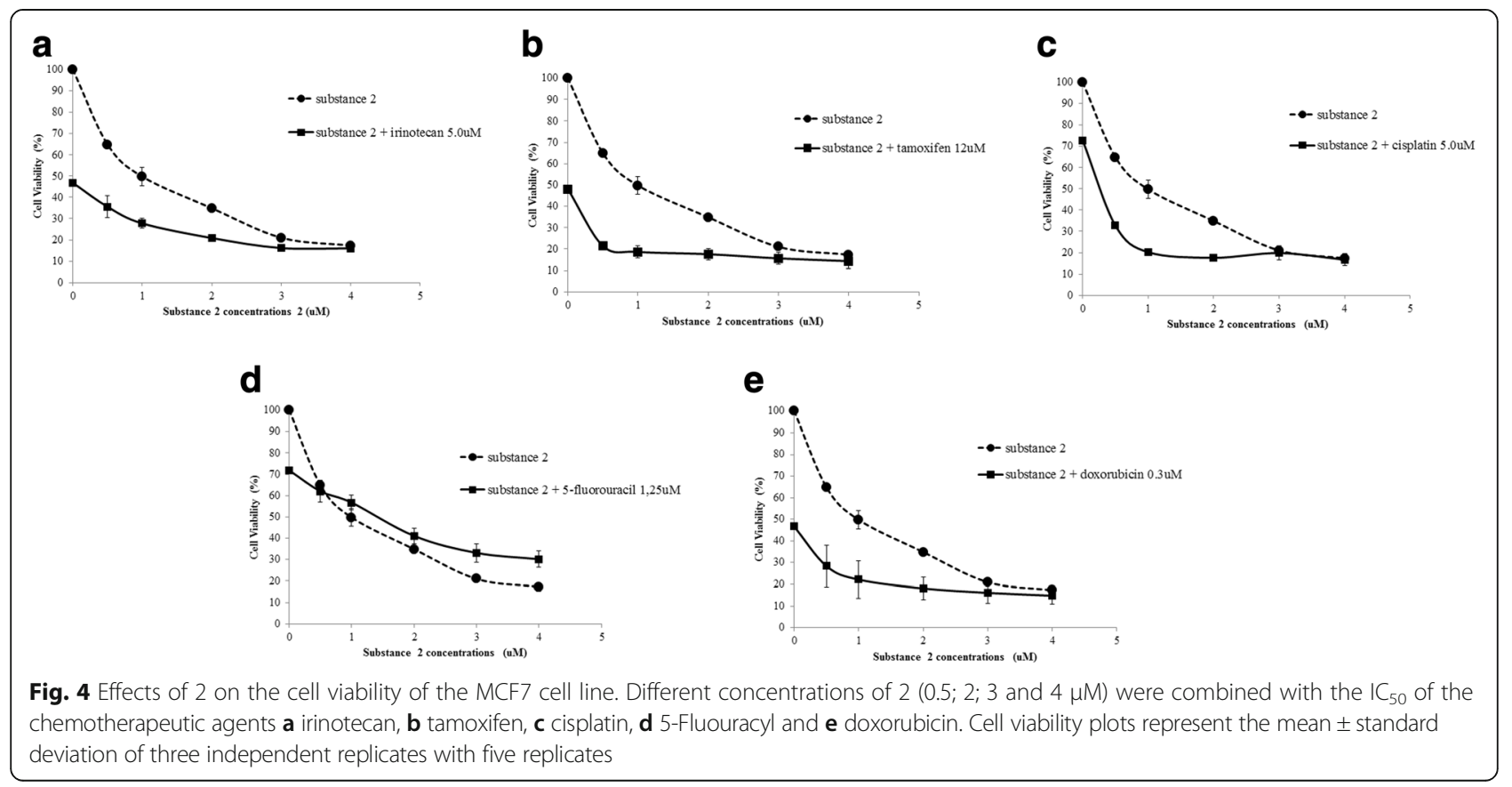




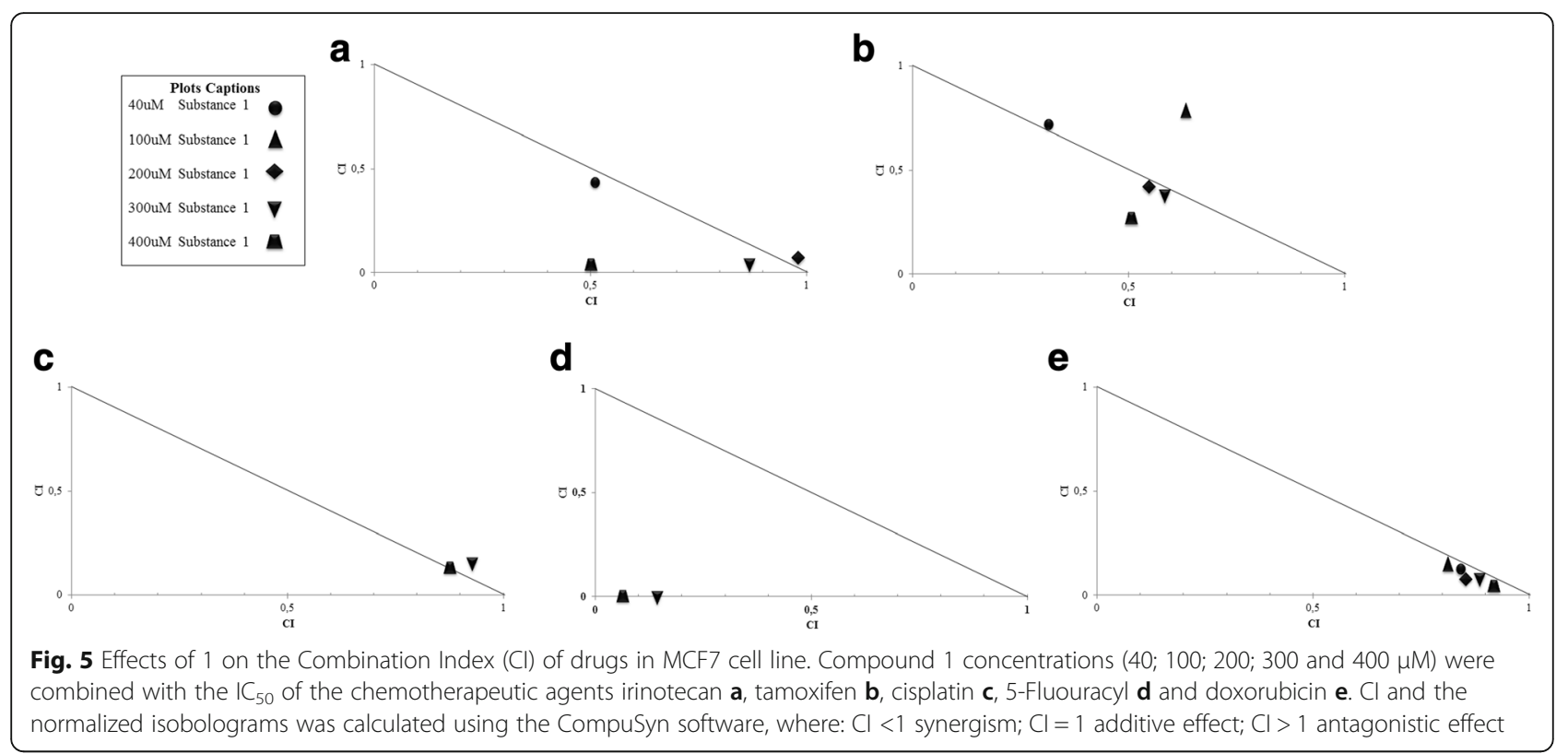

combinations with 5-fluorouracyl showed severe antagonism (Fig. 6d).

\section{Compounds 1 and 2 induce cell death by apoptosis}

The results showed that both sesquiterpene lactones induced cell death by apoptosis after $4 \mathrm{~h}$ treatment and in the protocol of $4 \mathrm{~h}$ followed by post-incubation in drugfree medium for $24 \mathrm{~h}(4+24 \mathrm{~h})$.

In the treatments with the isolated compounds, carried out with post-incubation, an increase in the number of apoptotic cells was observed. This is especially true at concentrations of $28 \mu \mathrm{M}$ for 1 and $2.0 \mu \mathrm{M}$ for 2 , reaching values of $33.5 \pm 3.77$ and $60.25 \pm 10.03$ cells in apoptosis, respectively. Although both isolates induce apoptosis, 2 showed even higher rates of cell death compared with 1 (Table 1 ).

In the combined treatments, 1 was seen to increase the amount of cells in apoptosis compared with doxorubicin after $4 \mathrm{~h}$ of treatment. However, the same was not seen for all post-incubation treatments, only for the association of $28 \mu \mathrm{M} 1$ with doxorubicin.

In the combined treatments of 2 and doxorubicin, it was observed a statistically significant increase of cells at programmed cell death at concentration of $2.0 \mu \mathrm{M}$ in both treatments: $4 \mathrm{~h}$ and $4 \mathrm{~h}$ plus $24 \mathrm{~h}$ in drug-free medium.

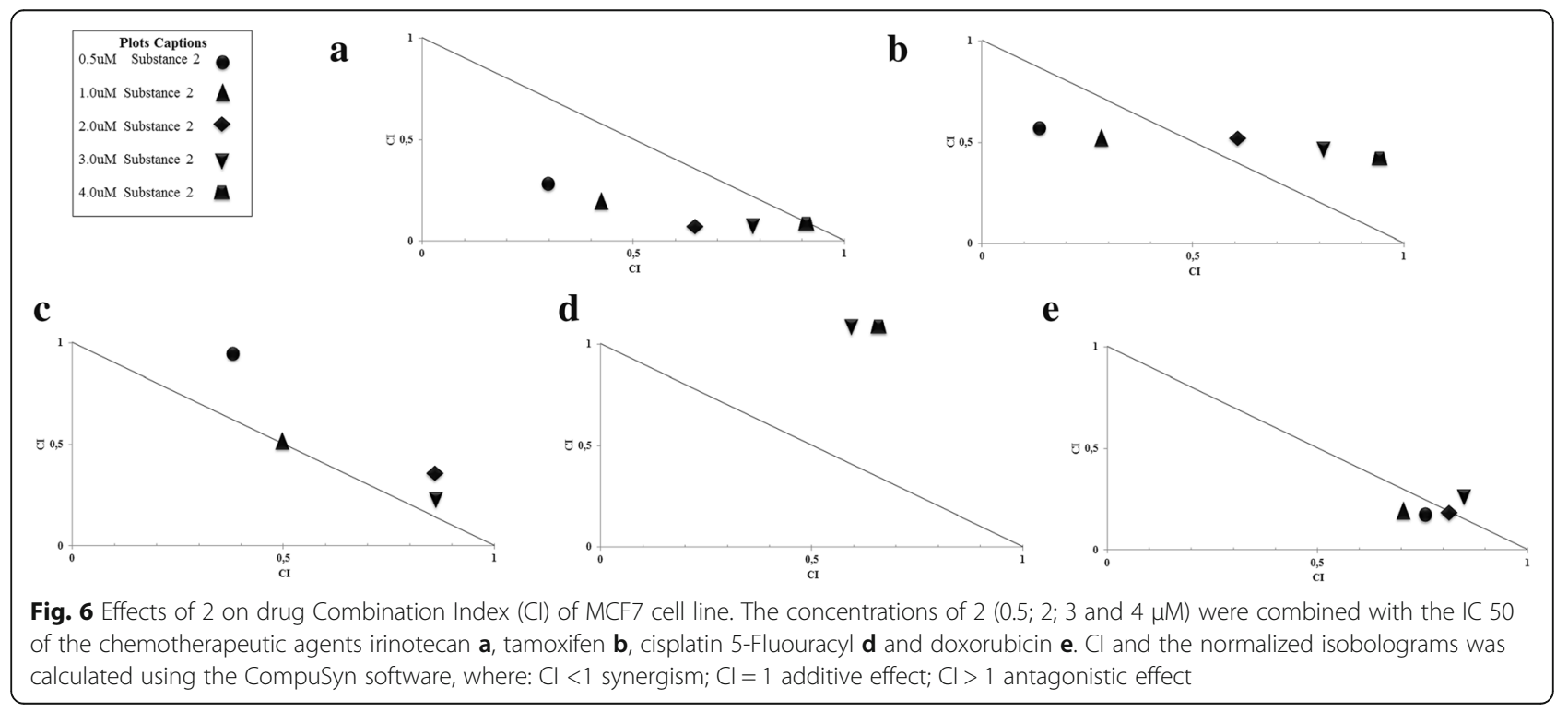


Table 1 Mean and standard deviation of apoptotic MCF-7 cells after 4 and 24 h exposure at three concentrations of compound 1 (11,13-diidrozaluzanin C) and 2 (Gochnatiolide C) associated with doxorubicin

\begin{tabular}{|c|c|c|c|}
\hline \multirow[t]{2}{*}{ Concentrations } & \multicolumn{2}{|l|}{ Apoptosis Assay } & \multirow{2}{*}{$\begin{array}{l}\text { Comparison } \\
\text { between } 4 \\
\text { and } 24 \mathrm{~h}\end{array}$} \\
\hline & Mean of apoptotic cells \pm SD (4 h) & Mean of apoptotic cells \pm SD (24 h) & \\
\hline Control & $4.00 \pm 1.87^{a}$ & $10.75 \pm 2.86^{\mathrm{a}}$ & $p>0,05$ \\
\hline Doxorrubicin (D) - $0.3 \mu \mathrm{M}$ & $33.25 \pm 5.34^{\mathrm{b}}$ & $61.75 \pm 10.82^{b}$ & $*$ \\
\hline \multicolumn{4}{|c|}{ 11,13-diidrozaluzanin C (Compound 1) } \\
\hline Compound $1-14 \mu \mathrm{M}$ & $16.00 \pm 1.87^{c}$ & $23.25 \pm 3.83^{b}$ & * \\
\hline Compound 1-28 $\mu \mathrm{M}$ & $24.25 \pm 5.71^{b, c}$ & $33.5 \pm 3.77^{c}$ & $p>0,05$ \\
\hline Compound $1-56 \mu \mathrm{M}$ & $21.5 \pm 4.83^{\mathrm{b}, \mathrm{c}}$ & $17.5 \pm 2.95^{\mathrm{a}}$ & $p>0,05$ \\
\hline Compound 1-14 $\mu \mathrm{M}+\mathrm{D} 0.3 \mu \mathrm{M}$ & $47.00 \pm 6.07^{b}$ & $47.25 \pm 5.21^{b}$ & $p>0,05$ \\
\hline Compound1 - $28 \mu \mathrm{M}+\mathrm{D} 0.3 \mu \mathrm{M}$ & $39.75 \pm 8.19^{b}$ & $51.25 \pm 10.2^{b}$ & $p>0,05$ \\
\hline Compound1 - $56 \mu \mathrm{M}+\mathrm{D} 0.3 \mu \mathrm{M}$ & $52.25 \pm 9.8^{b}$ & $31.5 \pm 4.6^{c}$ & * \\
\hline \multicolumn{4}{|l|}{ Gochnatiolide C (Compound 2) } \\
\hline Compound $2-0.5 \mu \mathrm{M}$ & $24.50 \pm 2.69^{b}$ & $40.00 \pm 4.94^{c}$ & * \\
\hline Compound 2-1.0 $\mu \mathrm{M}$ & $41.75 \pm 10.05^{b, c}$ & $51.50 \pm 7.69^{b}$ & $p>0,05$ \\
\hline Compound 2-2.0 $\mu \mathrm{M}$ & $53.25 \pm 6.13^{c}$ & $60.25 \pm 10.03^{b}$ & $p>0,05$ \\
\hline Compound 2-0.5 $\mu \mathrm{M}+\mathrm{D} 0.3 \mathrm{M}$ & $31.25 \pm 4.20^{b}$ & $31.25 \pm 5.76^{c}$ & $p>0,05$ \\
\hline Compound 2-1.0 $\mu \mathrm{M}+\mathrm{D} 0.3 \mu \mathrm{M}$ & $40.00 \pm 5.43^{b}$ & $45.25 \pm 4.14^{c}$ & $p>0,05$ \\
\hline Compound 2-2.0 $\mu \mathrm{M}+\mathrm{D} 0.3 \mu \mathrm{M}$ & $46.25 \pm 4.44^{\mathrm{b}, \mathrm{c}}$ & $62.00 \pm 7.51^{b}$ & * \\
\hline
\end{tabular}

Frequency of apoptotic cells after 4 and $24 \mathrm{~h}$ of test - free medium. SD: Standard Deviation. Compound 1 at concentrations of $14 ; 28$ and $56 \mu \mathrm{M}$ Compound 2 at concentrations of $0.5 ; 1.0$ and $2.0 \mu \mathrm{M}$ combined or not with doxorubicin IC 50 in MCF7 breast cancer cell line. We analyzed 100 cells, the data represent mean and standard deviation of the average of two independent replicates with two replicates. Different letters indicate statistically significant differences. The results were evaluated by NPAR1WAY/Wilkoxon. Significance * $p<0.05$

When comparing the different protocols ( $4 \mathrm{~h}$ and $4 \mathrm{~h}$ $+24 \mathrm{~h}$ ) as to the mean and standard deviation obtained, a statistically significant reduction (more than half) was detected in the number of cells in apoptosis in the combined treatment of $156 \mu \mathrm{M}$ and doxorubicin. Also statistically significant is the increased apoptotic activity present in the cells treated with doxorubicin and $2.0 \mu \mathrm{M}$ 2 combined (Table 1).

\section{The lactones of M. polymorphum subsp. floccosum decrease cell proliferation}

The results of the cell proliferation evaluation trial demonstrated that both 1 and 2 decreased mitotic activity of MCF-7 cells, and the effect of 2 being more pronounced than that of 1 , both in isolation and in combination with doxorubicin.

It is observed that the mean cell division is 1.63-fold reduced when 1 is tested alone, and 1.82-fold when tested in combination with doxorubicin. This reduction is 2.08-fold when 2 is tested alone and 2.71-fold when combined with chemotherapy (Table 2).

\section{Discussion}

Breast cancer is a disease whose incidence and mortality have increased in recent years, a fact that burdens the government funds since the treatments are long-lasting and expensive [2]. Chemotherapy with cytotoxic/ cytostatic agents may be inefficient. Thus, the search for more effective treatments has become one of the important targets in the study of pharmacogenetics and pharmacogenomics in cancer $[4,5]$.

Combined therapy is the most frequently used form of anti-cancer treatment to achieve (i) synergistic therapeutic effects; (ii) dose and toxicity reduction; and (iii) delay and/or minimization of drug resistance induction $[20,21]$. To that end, sesquiterpene lactones (1 and 2) were tested with commercial chemotherapeutic agents that have different mechanisms of action in order to potentiate their antitumor effects in MCF-7 cells, an in vitro screening model for the treatment of breast cancer.

The results demonstrate that, when tested alone, sesquiterpene lactones 1 and 2 reduce cell viability by the MTT assay, being 2 the most active compound. The cytotoxic activity of these compounds have been ever described in previous study using the sulphorhodamine $B$ method [10]. However this study demonstrates in a pioneering way that these two lactones cause cell death by apoptosis (differential assay of cell death - apoptosis $\mathrm{x}$ necrosis, differential staining by ethidium bromide and acridine orange) and reduce cell proliferation (cell proliferation assay with BrdU), although with different powers. These findings allow us to infer that the compounds have cytotoxic and cytostatic action in breast tumor 
Table 2 Effect of treatment with compound 1 (11,13diidrozaluzanin C) and 2 (Gochnatiolide C) on the cell cycle in MCF-7 cells associated or not to Doxorubicin. Mean \pm standard deviation and reduction ratio of mitotic activity of tested cells

\begin{tabular}{|c|c|c|}
\hline \multirow[t]{2}{*}{ Concentrations } & $\begin{array}{l}\text { Frequency of cells } \\
\text { in mitotic activity }\end{array}$ & \multirow[t]{2}{*}{ MARR } \\
\hline & Mean \pm SD & \\
\hline Control & $77.5 \pm 4.03^{\mathrm{a}}$ & - \\
\hline Doxorrubicin (D) - $0.3 \mu \mathrm{M}$ & $35.25 \pm 4.5^{\mathrm{b}}$ & 2.19 \\
\hline \multicolumn{3}{|c|}{ 11,13-diidrozaluzanin C (Compound 1) } \\
\hline Compound 1-28 $\mu \mathrm{M}$ & $47.5 \pm 5.25^{c}$ & 1.63 \\
\hline Compound 1-28 $\mu \mathrm{M}+\mathrm{D} 0.3 \mu \mathrm{M}$ & $42.5 \pm 7.85^{\mathrm{b}, \mathrm{c}}$ & 1.82 \\
\hline \multicolumn{3}{|l|}{ Gochnatiolide C (Compound 2) } \\
\hline Compound 2-1.0 $\mu \mathrm{M}$ & $37.25 \pm 3.09^{b}$ & 2.08 \\
\hline Compound 2-1.0 $\mu \mathrm{M}+\mathrm{D} 0.3 \mu \mathrm{M}$ & $28.5 \pm 7.5^{\mathrm{b}}$ & 2.71 \\
\hline
\end{tabular}

Frequency of cells in mitotic activity. Compound 1 at the concentration of $28 \mu \mathrm{M}$ and compound 2 at the concentration of $1.0 \mu \mathrm{M}$ combined or not with IC 50 of doxorubicin in MCF7 breast adenocarcinoma cells. SD: Standard Deviation. MARR - Mitotic Activity Reduction Ratio was obtained by calculating the ratio from the value of the control mean divided by the results obtained in the means of the tests. We analyzed 100 cells, the table represents mean and standard deviation of the mean of two independent replicates with two replicates. Different letters indicate statistically significant differences. The results were evaluated by NPAR1WAY/Wilkoxon. Significance ${ }^{*} p<0.05$

cells, which suggests relevant chemotherapeutic action for the treatment of the disease.

In previous studies [22], it has been shown that cytostatic/cytotoxic action of sesquiterpene lactones can be carried out by means of a selective allocation, via the addition of Michel, of the sulfhydryl groups of the lysosomal enzymes. This fact resulted in the reduction of DNA synthesis and consequent decrease in the uncontrolled growth of tumor cells. However, such a mechanism is present in compounds having a double bond conjugated with a carbonyl, which is a structure present only in compound 2 .

Because 1 has a different chemical structure, lacking the $\alpha$-methylene- $\gamma$-lactone group, it is understood that its action mechanism is different from that of 2 . Previous studies [13] indicate that 1 has anti-inflammatory action determined by the reduction of cytokine TNF- $\alpha$ levels. It is known that this cytokine is determinant in the tumor microenvironment, promoting proliferation and invasion of tumor cells, TNF- $\alpha$ also positively regulates antiapoptotic proteins. Thus, its reduction by the presence of 1 , can lead to the release of cytochrome c, consequently increase of caspase proteins, and finally triggering the apoptotic event [23].

These important antitumor results evidenced for the sesquiterpene lactones ( 1 and 2 ) have aroused interest in knowing their effects in association with commercial chemotherapeutic agents, which are cell damageinducing agents widely used in anticancer therapies.
In the combined studies of 1, this compound was observed to increase the effects of drugs irinotecan, tamoxifen and doxorubicin. From the cell viability curves of these associations, the CIs were calculated, which confirmed the responses obtained by the MTT assay demonstrating additive effect and synergism for these combinations. However the combination of 1 with cisplatin and 5-fluorouracyl has been shown to be antagonistic to these chemotherapeutics. Thus the data suggest that 1 may be an important compound for the development of antitumor therapies combined with irinotecan, tamoxifen and doxorubicin, but our findings discourage its association with cisplatin and 5-fluorouracyl.

In turn, experiments combined with 2 demonstrated potentiation of the effects with irinotecan, tamoxifen, cisplatin and doxorubicin. CI values confirmed the responses obtained in the MTT assay and indicated additive effects for the different concentrations of 1 combined with tamoxifen and cisplatin, and synergism for irinotecan and doxorubicin. The combination with 5-fluorouracyl, however, demonstrated antagonism. Therefore the results discourage the combined use of 2 and 5-fluorouracyl in the development of anticancer therapies.

The variations in the responses of associations (additive effect, synergism or antagonism actions) may occur because of the different mechanisms of action of the chemotherapeutic agents tested and also because of the influence of 1 and 2 on them. Irinotecan belongs to a class of anticancer agents that act directly on enzyme topoisomerase I, causing genomic instability that leads to cell death by apoptosis [24, 25]. Tamoxifen is an antineoplastic agent that has affinity for estrogen receptors in mammary cells, thus turning to be an antagonist of cell growth. Doxorubicin acts on three different fronts (i) by altering the fluidity of the cell membrane; (ii) by forming free radicals by enzymatic reduction; and finally (iii) by blocking the DNA and RNA synthesis through the reduction the topoisomerase II activity [24, 26]. Cisplatin's mechanism is related to the selective inhibition of DNA synthesis because of its alkylating activity [27]. 5-fluorouracyl is considered to be a drug belonging to the antimetabolite class capable of chemically blocking DNA synthesis as it is a base analogue. However, for its activity to occur, 5-fluorouracyl must be converted into its metabolites and these, in turn, incorporated into RNA (fluorouridine triphosphate - FUTP) or DNA (fluorouridine deoxyuridine triphosphate - FdUTP) in the presence of amino acid cysteine, thus preventing cell replication $[7,28]$.

Our results have demonstrated that 1 can induce cell death and improve the action of irinotecan, tamoxifen and doxorubicin by additive effect and/or synergism; and that 2 may favor the effects of tamoxifen and cisplatin by additive effect, and of irinotecan and doxorubicin by 
synergism. Regarding 5-fluouracyl, it was observed that the two sesquiterpene lactones are able to influence its mechanism of action and thus reduce its ability to cause cell death indicating antagonism in association with either 1 or 2 . The same antagonistic effect occurred in the combination of cisplatin and 1 .

Concerning the mechanism of action of sesquiterpene lactones, studies have demonstrate, in general, that they act in the signaling pathway of NF-kB, a transcription factor that regulates the expression of more than 150 genes related to the immune response, to intracellular stress, to stimulation of cell division and to inhibition of apoptosis (Heyden and Ghosh, 2008; Li, et al., 2015). It is inferred that due to the presence of the double bond conjugated with the carbonyl, compound 2 acts on the NF-kB signaling pathway through alkylation, via Michel addition, in the presence of $\alpha$-methylene- $\gamma$-lactone rings. This alkylation leads to the covalent bond of the p65 subunit of NF-kB and cysteine, resulting in a conformational change of NF- $\mathrm{kB}$ that inhibits its activity [22, 29]. Compound 1 has no double bond conjugated to a carbonyl in its structure, yet it negatively regulates an expression of TNF- $\alpha$, cytokine is also regulated by the transcription factor NF-kB [13].

The cisplatin, that acts by selective inhibition of DNA synthesis owing to its alkylating activity [27], presented distinct results for 1 and 2, being an antagonist for the former and additive agent for the latter. It is therefore assumed that the alkylating activity can be influenced by sesquiterpene lactones. The antagonistic action of 1 and cisplatin allows us to infer that these two compounds compete for actions sites, which would reduce the cisplatin ability to cause cell death in the MCF-7 lineage. The same effect, however, was not observed in 2 , a fact that could be related to the different alkylation sites of 1 and 2 .

5-Fluorouracyl, that requires cysteine [28] to play an anti-cancer role, is believed to lose part of its activity because of the competition of the compound 2 for this amino acid. Thus, the more $\alpha$-methylene- $\gamma$-lactone rings, the more alkylation events; a larger number of NF- $\mathrm{KB}$ enzymes is inhibited and a larger number of cysteines is required [22]. Following this logic, it is inferred that there is reduced intracellular cysteine bioavailability to make the mechanisms of action of 5-fluorouracyl effective in the presence of 2, which explains the antagonistic effects observed in this study.

The 5-fluorouracyl has a mechanism of action very similar to the compounds tested, suppressing the transcription factor NF-kB. The antagonistic action of the association between 5-fluorouracyl and compound 1 is present in the lowest doses (40; 100 and $200 \mu \mathrm{M})$; but, in the highest concentrations ( 300 and $400 \mu \mathrm{M}$ ) a synergistic action is observed. This synergism is explained by the combined action of the tested compounds on the reduction of the expression of genes involved in cell proliferation [14]. However, the antagonism of the lower doses should be better studied with different concentrations and in other cell lines.

Even with differentiated responses, the combination of sesquiterpene lactones and doxorubicin can lead to certain linearity, that is, the associations showed synergistic activity with 1 and 2 . This fact determined the choice of this anticancer agent for the assays of evaluation of death and cell proliferation.

In this assay three concentrations of 1 and 2, within the $\mathrm{IC}_{50}$ range, were tested in combination with doxorubicin in two experimental protocols: (i) continuous treatment for $4 \mathrm{~h}$ and (ii) continuous treatment for $4 \mathrm{~h}$ followed by a 24 h-post-incubation in drug-free medium. In carrying out the protocol, it was investigated whether, by removing the treatment, the effects are reduced by DNA repair or if they are potentiated, since the primary lesions may become secondary as a result of an attempted repair [22].

In both experiments, 2 presented higher apoptotic activity, and in the post-incubation treatments an increase occurred in cell death when compared with the $4 \mathrm{~h}$ protocol. Differently, after the post-incubation period, 1 did not cause an enhanced reduction in cell viability as 2 did. These events can be elucidated if the structures of 1 and 2 are taken into account. The sesquiterpene lactone 1 has no exocyclic double bond, which could explain the different mechanisms of action presented. This fact is corroborated by the higher cytotoxic efficacy of 2 in previous studies [10].

In this same assay, when there is a combination of lactones with doxorubicin, an increase in the average number of cells in apoptosis is observed. However there is no dose-dependent response in either of the two evaluated compounds. When the capacity of damage potentiation after $24 \mathrm{~h}$ of treatment is evaluated, the phenomenon is seen to occur only in the lowest doses of the compounds when tested alone, and in the highest doses when tested in association with the chemotherapeutic.

These events are believed to be closely related to the different mechanisms of action of the tested chemotherapeutic agents and compounds, corroborating the hypothesis that, because they act in different metabolic pathways of death and mechanisms of cell cycle arrest, they are complementary and can favor the development of new anticancer therapies.

In addition, both 1 and 2 have effective antiproliferative action. In combined treatments, a reduced cell proliferation was observed for both isolates. Although 2 showed more successful results when isolated or associated with doxorubicin. These events corroborate the results obtained in the previous assays, indicating that 
compounds 1 and 2 act as antiproliferative agents by activating apoptotic events.

\section{Conclusions}

Finally, it can be deduced that sesquiterpene lactones have therapeutic potential for developing anticancer therapies. It is also noteworthy that these compounds can be used in combination with doxorubicin, since they are capable of causing changes in DNA synthesis and regulating the apoptosis mechanism, events that, through the action of the sesquiterpene lactones, lead to reduced toxicity.

Furthermore, the tested compounds have the ability to exert a synergistic action on doxorubicin, possibly by down-regulating the drug resistance mechanisms. However, it is observed that compound 2 is highlighted in its action because smaller doses are required for a performance with good efficiency, unlike compound 1. All the points aforementioned lead to the conclusion that the studied sesquiterpene lactones, especially isolated compound 2, have therapeutic potential for isolated use and/ or combined application with irinotecan, tamoxifen and, especially, doxorubicin.

\section{Abbreviations}

1: 1113 - diidrozaluzanin C; 2: Gocnatiolide C; Brdu: 5 - bromodeoxyuridine; Cl: Combination Index; FA: Affected cell fraction; h: Hours; MARR: Mitotic Activity Reduction Ratio; MTT: 3-(4,5-dimetilltiazol-2-il)-2,5-difeniltetrazol bromide

\section{Acknowledgements}

The present research group thanks the Federal University of Mato Grosso do Sul and the Graduate Program in Biotechnology and Biodiversity for stimulating and supporting this study

\section{Funding}

This study was funded by the Foundation for Support to the Development of Education, Science and Technology of the State of Mato Grosso do Sul (FUNDECT), the Coordination of Improvement of Higher Education Personnel (CAPES), and the National Research Council (CNPq).

\section{Availability of data and materials}

The datasets generated and/or analysed during the current study are not publicly available due because the compounds studied are in patent deposition process, but are available from the corresponding author on reasonable request.

\section{Authors' contributions}

MOM- Wrote the manuscript and developed the cell cultures and microscopic analyzes of the experimental results. RM - Contributed substantially to the conception and design of the experiment, in addition to having performed the statistical analysis of the IC50 of the chemotherapeutic agents used. ND - Assisted in data acquisition of the trials of apoptosis and proliferation, as well as collaborating with the construction of isobolograms. RLBS- Responsible for isolation of the tested compounds and contributed to the critical revision of the article. RJO - Professor responsible for the laboratory which the research was developed and assisted in the interpretation of the data. MES - Yielded the isolated compounds for testing and aided in writing the article. CLK- Assisted in the interpretation of the data. MFCM- Gave the cells to perform the experiment and contributed to the critical revision of the article. FJCF - Responsible for statistical analysis. DSC- Guiding professor of Mariana de Oliveira Mauro, and he made substantial contributions to conception and design, in addition to the interpretation of statistical data. All authors read and approved the final manuscript.

\section{Competing interests}

The authors declare that they have no competing interests.

Consent for publication

Not applicable.

Ethics approval and consent to participate

Not applicable.

\section{Publisher's Note}

Springer Nature remains neutral with regard to jurisdictional claims in published maps and institutional affiliations.

\section{Author details}

${ }^{1}$ Programa de Pós-Graduação em Biotecnologia e Biodiversidade, Doutorado Rede Pró Centro-Oeste, Universidade Federal de Mato Grosso do Sul (UFMS), Campo Grande, Mato Grosso do Sul 79070-900, Brazil. ${ }^{2}$ Programa de Mestrado em Farmácia, Centro de Ciências Biológicas e da Saúde (CCBS), Universidade Federal de Mato Grosso do Sul (UFMS), Campo Grande, Mato Grosso do Sul, Brazil. ${ }^{3}$ Departamento de Química, Universidade Federal do Paraná (UFPR), Curitiba, Paraná, Brazil. ${ }^{4}$ Centro de Estudos em Células Tronco, Terapia Celular e Genética Toxicológica (CeTroGen), Hospital Universitário Maria Aparecida Pedrossian (HUMAP), Universidade Federal de Mato Grosso do Sul (UFMS), Campo Grande, Mato Grosso do Sul, Brazil. ${ }^{5}$ Faculdade de Ciências da Saúde, Universidade Federal da Grande Dourados (UFGD), Dourados, Mato Grosso do Sul, Brazil. ${ }^{6}$ Faculdade de Medicina Veterinária e Zootecnia (FAMEZ), Universidade Federal de Mato Grosso do Sul (UFMS), Campo Grande, Mato Grosso do Sul, Brazil.

Received: 12 February 2017 Accepted: 15 June 2017

Published online: 29 June 2017

\section{References}

1. Meresse M, Bouhnik AD, Bendiane MK, Retornaz F, Rousseau F, Rey D, Giorgi $\mathrm{R}$, Chemotherapy in Old Women with Breast Cancer: Is Age Still a Predictor for Under Treatment? Breast J. 2016. doi:10.1111/tbj.12726.

2. Siegel R, Jiemin MA, Zhaohui Z, Ahmedin J. Cancer Statistics. Cancer J Clin. 2014;64:9-29.

3. Alsafadi S, Even C, Falet C, Goubar A, Commo F, Scott V, Quidville V, Albiges L, Dieci MV, Guegan J, Lazar V, Ahomadegbe JC, Delaloge S, André F. Retinoic acid receptor alpha amplifications and retinoic acid sensitivity in breast cancers. Clin Breast Cancer. 2013;13:401-8.

4. Ferlay J, Soerjomataram I, Dikshit R, Eser S, Mathers C, Rebelo M, Parkin DM, Forman D, Bray F. Cancer incidence and mortality worldwide: Sources, methods and major patterns in GLOBOCAN 2012. Int J Cancer. 2014;136:359-86.

5. Gupta A, Mutebi M, Bardia A. Gene-expression-based predictors for breast cancer. Ann Surg Oncol. 2015;22:3418-32.

6. Genestreti G, Battista M, Cavallo G, Brandes A. First-Line Platinum-Based Chemotherapy Re-challenge in Sensitive Small Cell Lung Cancer (SCLC): A Standard Treatment? Chemo Open Access. 2015:4:1-2.

7. Gajsk G, Gerić M, Domijan AM, Garaj-Vrhovac V. Combined cyto/genotoxic activity of a selected antineoplastic drug mixture in human circulating blood cells. Chemosphere. 2016;165:529-38.

8. Zhao L, Jessie LS, Wientje MGS. Comparison of methods for evaluating drug-drug interaction. Front Biosci. 2010;2:241-9.

9. Goyal S, Gupta N, Chatterjee S, Nimesh S. Natural Plant Extracts as Potential Therapeutic Agents for the Treatment of Cancer. Curr Top Med Chem. 2016; 17:96-106.

10. Strapasson RLB, Armando CC, Carvalho JE, Ruiz ALTG, Salvador MJ, Stefanello MEA. Bioactivity-guided isolation of cytotoxic sesquiterpene lactones of Gochnatia polymorpha ssp. floccosa. V Phytother Res. 2012;26:1053-6.

11. Strapasson RLB, Hernandez-Tasco A, Salvador MJ, Stefanello MEA. Antioxidant activity and HPLC-DAD profile of Moquiniastrum polymorphym subsp. floccosum (Asteraceae). Lat Am J Pharm. 2017;36:200-4.

12. Schlemper V, Freitas SA, Schlemper SEM. Antispasmodic effects of hydroalcoholic extract from Gochnatia polymorpha ssp. floccosa in the guinea pig ileum. Res J Med Plant. 2011;5:288-94.

13. Piornedo RR, Souza P, Stefanello ME, Strapasson RL, Zampronio AR, Kassuya CA. Anti-inflammatory activity of extracts and 11,13-dihydrozaluzanin C from Gochnatia polymorpha ssp. floccosa trunk bark in mice. J Ethnopharmacol. 2011;133:1077-84 
14. Martins CG, Lívero FAR, Stolf AM, Kopruszinski CM, Cardoso CC, Beltrame OC, Queiroz-Telles JE, Strapasson RLB, Stefanello MEA, Oude-Elferink R, Acco A. Sesquiterpene lactones of Moquiniastrum polymorphum subsp. floccosum have antineoplastic effects in Walker-256 tumor-bearing rats. Chem Biol Interact. 2015;228:46-56.

15. Strapasson RLB. Constituintes químicos e avaliação das atividades citotóxica e antioxidante de Moquiniastrum polymorphum subsp. floccosum. Curitiba: Tese de doutoramento, Universidade Federal do Paraná; 2014.

16. Poindessous V, Koeppel F, Raymond E. Marked activity of irofulven toward human carcinoma cells : Comparison with cisplatin and ecteinascidin. Clin Cancer Res. 2003:9:2817-25.

17. Mauro MO, Sartori D, Oliveira RJ, Ishii PL, Mantovani MS, Ribeiro LR. Activity of selenium on cell proliferation, cytotoxicity, and apoptosis and on the expression of CASP9, BCL-XL and APC in intestinal adenocarcinoma cells. Mutat Res. 2011;715:7-12.

18. Chou TC, Talalay P. Analysis of combined drug effects: a new look at a very old problem. Trends Pharmacol Sci. 1983:4:450-4.

19. Oliveira R, Matuo R, Silva A, Matiazi H, Mantovani M, Ribeiro L. Protective effect of B-glucan extracted from Saccharomyces cerevisiae, against DNA damage and cytotoxicity in wild-type (k1) and repair-deficient (xr55) CHO cells. Toxicol in Vitro. 2007;21:41-52.

20. Chou TC. Drug combination studies and their synergy quantification using the Chou-Talalay Method. Cancer Res. 2010;12:440-6.

21. Chou TC. Theoretical basis, experimental design, and computerized simulation of synergism and antagonism in drug combination studies. Pharmacol Rev. 2006;68:621-81.

22. Li C, Jones AX, Lei X. Synthesis and mode of action of oligomeric sesquiterpene lactones. Nat Prod Rep. 2015;33:602-11.

23. Srinivasan S, Guha M, Kashina A, Avadhani NG. Mitochondrial dysfunction and mitochondrial dynamics-The cancer connection. Biochim Biophys Acta. 2017. doi:10.1016/j.bbabio.2017.01.004.

24. Brandão HN, David JP, Couto RD, Nascimento JAP, David JM. Química e farmacologia de quimioterápicos antineoplásicos derivados de plantas. Quim Nova. 2010;33:1359-69.

25. Efferth T, Li PCH, Konkimalla VSB, Kaina B. From traditional chinese medicine to rational cancer therapy. Trends Mol Med. 2007;13:353-61.

26. Goodin G. Oral chemotherapeutic agents: Understanding mechanisms of action and drug interactions. Am J Health Syst Pharm. 2007;64:S15-24.

27. Mitra K. Platinum complexes as light promoted anticancer agents: a redefined strategy for controlled activation. Dalton Trans. 2016;45:19157-1917.

28. Longley DB, Harkin DP, Johnston PG. 5-Fluorouracyl: mechanisms of action and clinical strategies. Nat Rev Cancer. 2003;3:330-8.

29. Hayden MS, Ghosh S. Shared principles in NF-kappaB signaling. Cell. 2008; 132:344-62.

\section{Submit your next manuscript to BioMed Central and we will help you at every step:}

- We accept pre-submission inquiries

- Our selector tool helps you to find the most relevant journal

- We provide round the clock customer support

- Convenient online submission

- Thorough peer review

- Inclusion in PubMed and all major indexing services

- Maximum visibility for your research

Submit your manuscript at www.biomedcentral.com/submit
Biomed Central 